

Bayero Journal of Pure and Applied Sciences, 8(1): $10-18$

Received: February, 2015

Accepted: June, 2015

ISSN $2006-6996$

\title{
THE EFFECT OF AQUEOUS STEM BARK EXTRACT OF ERYTHRINA MILDBRAEDII ON ACETAMINOPHEN INDUCED NEPHROTOXICITY IN RATS
}

\author{
* Wudil, A.M. and Sarki, S. I. \\ Department of Biochemistry, Bayero University, Kano-Nigeria. \\ *Correspondence author: amwudil@hotmail.com.
}

\begin{abstract}
This study was carried out to determine the curative effect of aqueous stem bark extract of Erythrina mildbraedii in rats induced with nephrotoxicity using $800 \mathrm{mg} / \mathrm{kg}$ Acetaminophen. Acetaminophen administration resulted in significant increase in the serum level of urea, creatinine, $\mathrm{Na}^{+}, \mathrm{K}^{+}, \mathrm{Cr}$ and a significant decrease in the level of $\mathrm{HCO}_{3}^{-}$. Administration of different doses $(50,100, \& 150 \mathrm{mg} / \mathrm{kg}$ ) of aqueous stem bark extract of Erythrina mildbraedii ameliorated the effect of Acetaminophen indicated by a significant decrease in the level of urea, creatinine, $\mathrm{Na}^{+}, \mathrm{K}^{+}, \mathrm{Cr}$ and an increase in the level of $\mathrm{HCO}_{3}^{-}$when compared to control rats. The histopathology showed a restoration of the renal architectures after administration of the aqueous stem bark extract.
\end{abstract}

Keywords: Acetaminophen, Erythrina mildbraedii, nephrotoxicity, aqueous extract.

\section{INTRODUCTION}

The kidney is the primary means of eliminating waste products of metabolism that are no longer needed by the body. The kidney participate in regulation of extracellular fluid volume, blood pressure, acid - base balance, and electrolyte balance. Blood - borne substances are exposed to kidney cells through the processes of filtration and reabsorption. A primary function of the kidney is to eliminate waste products. These products include urea (from the metabolism of amino acids), creatinine(from muscle creatine), uricacid(from nucleic acids), end products of hemoglobinbreakdown(such as bilirubin), and metabolites of various hormones. These waste products must be eliminated from the body as rapidly as they are produced. The kidneys also eliminate most toxins and other foreign substances that are either produced by the body or ingested, such as pesticides, drugs and food additives (Guyton and Hall, 2006). During the process of reabsorption, potentially toxic chemicals may achieve higher concentrations than present in plasma, which may predispose the kidney to injury (Hodgson, 2010).

The genus Erythrina mildbraedii (Minjirya in hausa)is known for its use in traditional medicine, especially for the treatment of microbial infections (Mitscher et al., 1987). Various parts (roots, barks, leaves and wood) of this plant are commonly used in African folk medicine (Burkill, 1995). Earlier works on the seeds of Erythina species revealed the presence of many physiologically active alkaloids. Erythrina mildbraedii is a tree growing up to $30 \mathrm{~m}$ in height and is native in West Africa, easy to cultivate, quick growing, large shrub. It flowers profusely (twice a year) and is a handsome sight (Heywood, 1996). As most of leguminoseae, Erythrina species produce many secondary metabolites, some of which have a function of defence systems against pathogenic fungi and bacteria (Karthishwaran et al., 2010). Ethnobotanical discovery process of sub-Saharan Erythrina has resulted in promising biological activities (Kone et al., 2004; Nguyen et al., 2010).

Up to date, a number of reports on this species revealed diverse biological activities: its seeds were reported to contain erythrinan alkaloids which might be related to its potential physiological activity (Amer et al., 1991). Three pterocarpans, erybraedin A, B and $\mathrm{C}$, isolated from the roots of Erythrina mildbraedii, were reported to be active against Staphylococcus aureus ATCC 13709 and Mycobacterium smegmatis ATCC 607 (Mitscher et al., 1988). The pterocarpene erycristagallin, isolated from the same species, has been reported to exhibit antiinflammatory activity (Njamen et al., 2003). Isoprenylated flavonoids isolated from the same species showed protein tyrosine phosphatase-1B inhibitory activity ( $\mathrm{Na}$ et al., 2006). Erythrina mildbraedii is used to prepare remedies against prostate (Tchokouaha et al., 2010).

Many Erythrina species showed real potential for fighting against pathogenic agents incrimated in alarming public health problems in subSaharan Africa. For e.g. multidrug resistant pathogens are responsible for therapeutic failures (Kone and Kamanzi, 2009). This situation is serious because microbial infections are most frequent opportunistic diseases occurring during HIV/AIDS which affected many people in Africa. Moreover, during this infection, cancer and cardiovascular diseases, oxidative stress and generating free radicals is recognized to cause damage in cell and immune system of patients. Scientists are searching for new molecules that can be alternative to conventional treatments (Coulidiati et al., 2011). 
High incidence of cancer, inflammation, and cardiovascular diseases are attributed to oxidative stress. Some Sub-Saharan Erythrina species are used by traditional practitioners to treat cancer and inflammation. These plants were investigated for cancer chemo protective agents and inhibitors of enzyme borne diseases. The studies were carried out on enzymes such as phospholipase C gamma 1,diacylglycerol acyltransferase (DGAT), protein tyrosin phosphatase 1 B(PTB 1B), ERK kinase,5lipooxygenase and 15-lipooxygenase. Inhibitors of these enzymes are proposed in the therapy of obesity, type 2 diabetes and cancer. Erythrina mildbraedii extract showed anti-inflammatory activity and radical scavenging activity in 1, 1-Diphenyl-2picrylhydrazyl (DPPH) assay (Njamen et al., 2003).

Acetaminophen is most widely used in the world as an analgesic and antipyretic drug that is safe at therapeutic dosages. However, it is also known to cause hepatic necrosis and renal failure in humans (Hengy et al., 2009) and animals (Ghosh et al., 2010) in overdoses Oxidative stress is reported to play a role in the pathogenesis of acetaminophen-induced renal damage whose metabolism occurs via cytochrome-P (CYP) ${ }_{450}$ enzymes in both the liver and the kidneys. In renal tissues, prostaglandin synthetase and $\mathrm{N}$-deacetylase enzymes play a key role in the formation of free radicals and their metabolites. At higher doses, acetaminophen is shunted through these pathways leading to the increased production of reactive oxygen/nitrogen metabolites, gradual GSH depletion, formation of lipid peroxidative products leading to cell death and renal failure (Abdel-Zaher et al., 2008; Ghosh et al., 2010). This research was carried out to evaluate the effect of aqueous stem bark extract of Erythrina mildbraedii on acetaminophen induced nephrotoxicity in rats.

\section{MATERIALS AND METHODS}

\section{Plant identification and Collection}

Erythrina mildbraedii stem bark was collected in October 2012 from Song local Government Area of Adamawa State. It was identified and authenticated by a Botanist at the Department of Plant Science, Faculty of Science, Bayero University Kano, Nigeria

\section{Extraction of Plant Materials}

The stem bark of the plant collected was carefully washed in clean water, and then dried at room temperature. They were pulverized to coarse powder and distilled water $\left(500 \mathrm{~cm}^{3}\right)$ was added to $100 \mathrm{~g}$ of the powdered stem bark in a conical flask. The content of the flask was then shaken and the top was covered with aluminium foil and kept for 48 hours. The extract was then obtained by filtration using whatman No 1 filter paper. The filtrate was dried and then reconstituted for administration.

\section{Experimental Animals}

Twenty four (24) white albino rats (weighing 160 to $250 \mathrm{~g}$ ) were purchased from the Animal house of the Biological Sciences Department, Bayero University,Kano. The rats were maintained under standard laboratory conditions and were allowed free access to both food and water throughout the period of the experiment.

The volume $\left(\mathrm{cm}^{3}\right)$ of the stem bark aqueous extract given to each rat was determined by its weight and required dose as follows:

Volume administered $\left(\mathrm{cm}^{3}\right)=$ weight of rat $(\mathrm{kg}) \times$ Required dose $(\mathrm{mg} / \mathrm{kg})$

Concentration of the extract $(\mathrm{mg} / \mathrm{cm} 3)$

\section{Experimental Design}

Twenty four (24) experimental rats were divided into eight groups of three (3) rats each. Kidney damage was induced in groups II - VIII using acetaminophen according to Adeneye et al. (2008) and Cekmen et al. (2009).

Group I: normal rats (no extract, no acetaminophen administered).

Group II: acetaminophen administered no extract (Test Control).

Group III: were administered with aqueous stem bark extract of Erythrina mildbraedii (Dose; $50 \mathrm{mg} / \mathrm{kg}$ orally, once daily for two weeks).

Group IV: were administered with aqueous stem bark extract of Erythrina mildbraedii

(Dose; $100 \mathrm{mg} / \mathrm{kg}$ orally, once daily for two weeks).

Group V: were administered with aqueous stem bark extract of Erythrina mildbraedii

weeks).

(Dose; $150 \mathrm{mg} / \mathrm{k}$ orally, once daily for two

Group VI: were administered with aqueous stem bark extract of Erythrina mildbraedii

(Dose; $50 \mathrm{mg} / \mathrm{kg}$ orally, once daily for four weeks).

Group VII: were administered with aqueous stem bark extract of Erythrina mildbraedii

daily for four weeks).

(Dose; $100 \mathrm{mg} / \mathrm{kg}$ orally, once

Group VIII: were administered with aqueous stem bark extract of Erythrina mildbraedii

(Dose; $150 \mathrm{mg} / \mathrm{kg}$ orally, once daily for four

weeks).

\section{Blood and Tissue Samples Collection}

Rats in groups I and II were sacrificed after $24 \mathrm{hrs}$ of acetaminophen administration to confirm kidney damage. Groups III- V were sacrificed after two weeks of extract administration, while groups VI- VIII were sacrificed after 4 weeks of extract administration.

The kidneys from all the rats were excised fixed in $10 \%$ buffered formaldehyde solution and used for histological examination.

\section{Biochemical Analysis}

Blood samples collected were allowed to clot and centrifuged at $2000 \mathrm{rpm}$ for $10 \mathrm{~min}$ to obtain the serum samples. For each serum sample, the level of creatinine by the method of Bartels and Bohmer (1972), 
Urea by the method of Weatherburn (1967), $\mathrm{Na}^{+}$by the method of Maruna (1958), $\mathrm{K}^{+}$by the method of Henry (1974), $\mathrm{Cl}^{-}$by the method of White (1970) and $\mathrm{HCO}_{3}{ }^{-}$by the method of Forrester et al. (1976) were analyzed to assess the kidney function.

\section{Histopathology}

Histological examinations were conducted using the method of Auwioro (2010). The kidney tissues were fixed in multiple baths of ethanol, embedded in paraffin,sectioned and stained with hematoxylin and eosin.

\section{Statistical Analysis}

The data was statistically analysed using one-way analysis of variance (ANOVA) with $\mathrm{P}$ value $<0.01$ considerd to be significant. Graphpad Instat 3 software (2000). Version 3.05, Graphpad Inc was used for all the analysis.

\section{RESULTS}

The nephrocurative property of the aqueous stem bark extract of Erythrina mildbraedii was evaluated two and four weeks after inducement of kidney damage. Table 1 shows the mean serum levels of creatinine, urea and electrolytes $\left(\mathrm{Na}^{+}, \mathrm{K}^{+}, \mathrm{Cl}^{-}\right.$, $\mathrm{HCO}_{3}{ }^{-}$) of test control rats 24 hours after administration of $800 \mathrm{mg} / \mathrm{kg}$ acetaminophen and that of normal rats (Group I) to confirm inducement of acute kidney failure. The result obtained showed a significant increase $(P<0.01)$ in the mean serum level of urea ,creatinine, $\mathrm{Na}^{+}, \mathrm{K}^{+}, \mathrm{Cl}^{-}$for the groups administered with acetaminophen while that of $\mathrm{HCO}_{3}{ }^{-}$decreased in the test control rats(Group II) when compared with the normal control rats(Group I). The result obtained after two weeks of oral administration of aqueous stem bark extract of Erythrina mildbraedii at a daily dose of 50, 100, $150 \mathrm{mg} / \mathrm{kg}$ (Table 1) showed a significant decrease $(\mathrm{P}<0.01)$ in the mean serum levels of $\mathrm{Na}^{+}, \mathrm{K}^{+}, \mathrm{Cl}^{-}$and that of urea and creatinine at $\mathrm{P}<0.01$ while that of $\mathrm{HCO}_{3}^{-} \quad$ increased significantly $(\mathrm{P}<0.01)$ when compared with test control rats but lower than that of the normal control groups. The decrease in the mean serum levels of $\mathrm{Na}^{+}, \mathrm{K}^{+}, \mathrm{Cl}^{-}$, urea and creatinine and increase in the level of $\mathrm{HCO}_{3}^{-}$was found to be dose dependent.

After four weeks of oral administration of aqueous stem bark extract of Erythrina mildbraedii the mean serum level of levels $\mathrm{Na}^{+}, \mathrm{K}^{+}, \mathrm{Cl}^{-}$, urea and creatinine, significantly decreased $(P<0.01)$ when compared with test control rats (Group II) while that of $\mathrm{HCO}_{3}{ }^{-}$increased significantly $(\mathrm{P}<0.01)$ when compared to test control rats (Group II) Table 2.

Plate 1 of the histopathology results showed photomicrograph of cross section of kidney of normal rats with normal kidney architecture. Plate 2 showed distortion of normal kidney architecture with dilation of renal tubules and collapsed Bowman's capsule due to damage caused by acetaminophen administration. Plates 3, 4 and 5 showed the cortex of the kidney consisting of numerous Bowman's capsules after administration of various doses of the extract for two weeks. Plates 6, 7 and 8 showed that the cortex also has numerous Bowman's capsules after administration of the extract for four weeks. 
Table 1: Effects of oral administration of aqueous stem bark extract on Erythrina mildbraedii ( ASBEEM) on serum biochemical indices of acetaminophen-induced nephrototoxicity in rats after two weeks

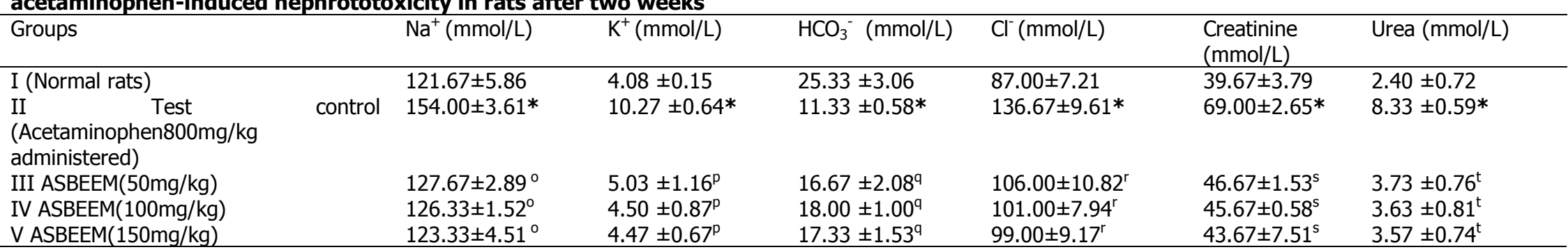

$17.33 \pm 1.53^{9}$

$99.00 \pm 9.17$

$43.67 \pm 7.51^{\mathrm{s}} \quad 3.57 \pm 0.74$

Values with asterisk are significantly different at $P<0.01$ when compared with normal rats.

Values in the same column bearing similar superscript are significantly different at $\mathrm{P}<0.01$ when compared to test control groups.

ASBEEM: Aqueous stem bark extract of Erythrina mildbraedii

Table 2: Effects of oral administration of ASBEEM on serum and biochemical indices of acetominophen-induced nephrototoxicity in rats after four weeks

\begin{tabular}{|c|c|c|c|c|c|c|}
\hline $\begin{array}{l}\text { Groups/Doses(mg/k } \\
\text { g) }\end{array}$ & $\mathrm{Na}^{+}(\mathrm{mmol} / \mathrm{L})$ & $\mathbf{K}^{+}(\mathrm{mmol} / \mathrm{L})$ & $\mathrm{HCO}_{3}{ }^{-}(\mathrm{mmol} / \mathrm{L})$ & $\mathrm{Cl}^{-}(\mathrm{mmol} / \mathrm{L})$ & $\begin{array}{l}\text { Creatinine( } \\
\mathrm{mmol} / \mathrm{L})\end{array}$ & Urea $(\mathrm{mmol} / \mathrm{L})$ \\
\hline I (Normal rats) & $121.67 \pm 5.86$ & $4.08 \pm 0.15$ & $25.33 \pm 3.06$ & $87.00 \pm 7.21$ & $39.67 \pm 3.79$ & $2.40 \pm 0.72$ \\
\hline $\begin{array}{l}\text { I Test control } \\
\text { (Acetominophen } 800 \mathrm{mg} / \\
\text { kg administerd) }\end{array}$ & $154.67 \pm 3.61 *$ & $10.27 \pm 0.64 *$ & $11.33 \pm 0.58 *$ & $136.67 \pm 9.61^{*}$ & $69.00 \pm 2.65 *$ & $8.33 \pm 0.59 *$ \\
\hline III ASBEEM $(50 \mathrm{mg} / \mathrm{kg})$ & $122.33 \pm 2.08^{\mathrm{u}}$ & $4.10 \pm 0.61^{v}$ & $20.67 \pm 2.08^{w}$ & $95.00 \pm 9.54^{x}$ & $44.00 \pm 3.46^{y}$ & $2.93 \pm 0.78^{z}$ \\
\hline IV ASBEEM $(100 \mathrm{mg} / \mathrm{kg})$ & $118.33 \pm 3.79^{\mathrm{u}}$ & $4.00 \pm 0.10^{v}$ & $21.33 \pm 1.53^{\mathrm{w}}$ & $90.00 \pm 10.00^{x}$ & $43.00 \pm 2.65^{y}$ & $2.63 \pm 0.64^{z}$ \\
\hline V ASBEEM $(150 \mathrm{mg} / \mathrm{kg})$ & $120.33 \pm 3.22^{\mathrm{u}}$ & $4.07 \pm 0.29^{v}$ & $22.67 \pm 1.53^{\mathrm{w}}$ & $85.00 \pm 5.00^{x}$ & $39.33 \pm 5.51^{y}$ & $2.36 \pm 3.06^{z}$ \\
\hline
\end{tabular}

Results are expressed as mean \pm SD for three determinations, $n=3$

Values with asterisk are significantly different at $P<0.01$ when compared with normal rats.

Values in the same column bearing similar superscript are significantly different at $\mathrm{P}<0.01$ when compared to test control groups

ASBEEM: Aqueous stem bark extract of Erythrina mildbraedii 
Plate 1 of the histopathology results shows photomicrograph of cross section of kidney of normal rats. Plate 2 shows the section of the kidney treated with $800 \mathrm{mg} / \mathrm{kg}$ acetaminophen. Plates 3,4 and 5 show cross section of the kidney treated with varying doses of ASBEEM for two weeks. Plates 6, 7 and 8 show cross section of the kidney treated with varying doses of ASBEEM for four weeks

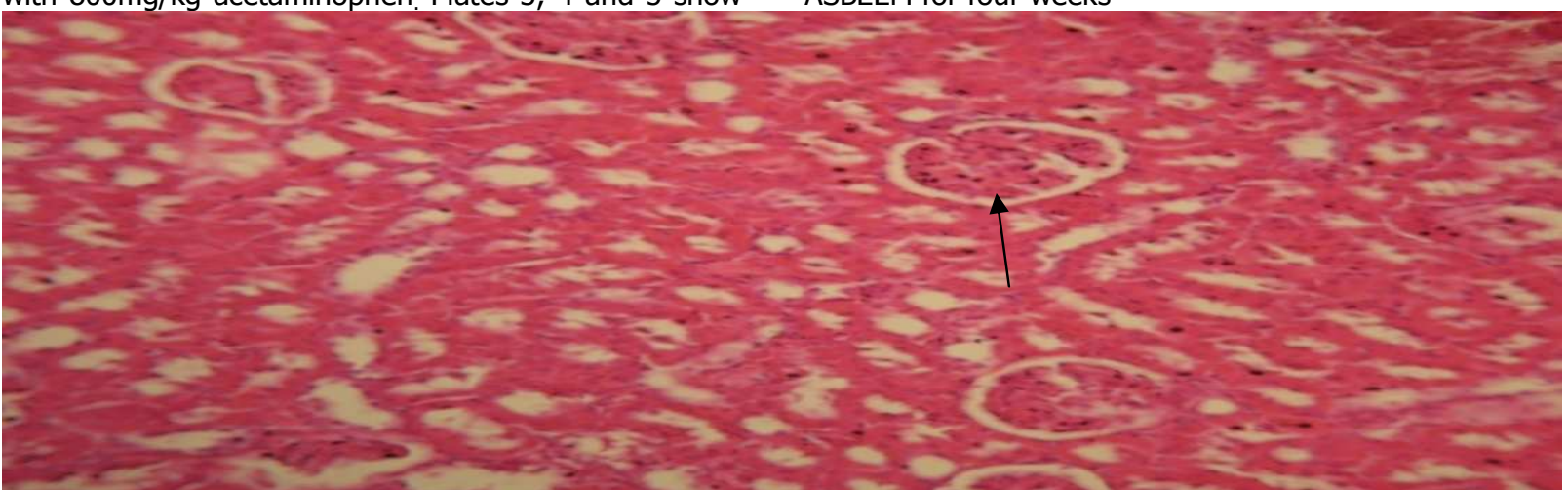

Plate 1: Shows normal kidney architecture with the cortex containing the glomerulus and the medulla containing the renal tubules. H \& E STAIN X 10

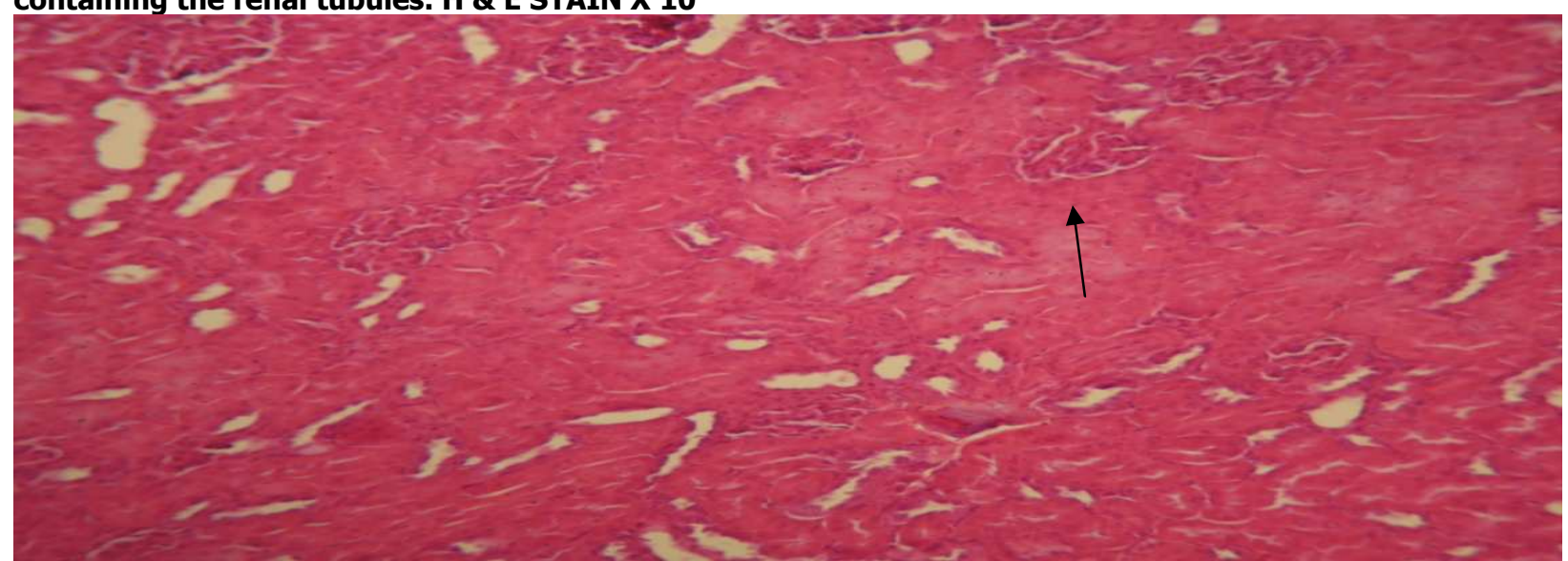

Plate 2: Section of the kidney shows distortion of the normal kidney architecture with dilation of the renal tubules and collapsed of Bowman's capsule due to damage caused by acetaminophen administered to the rats (Acetaminophen $800 \mathrm{mg} / \mathrm{kg}$ ).H \& E Stain X 10

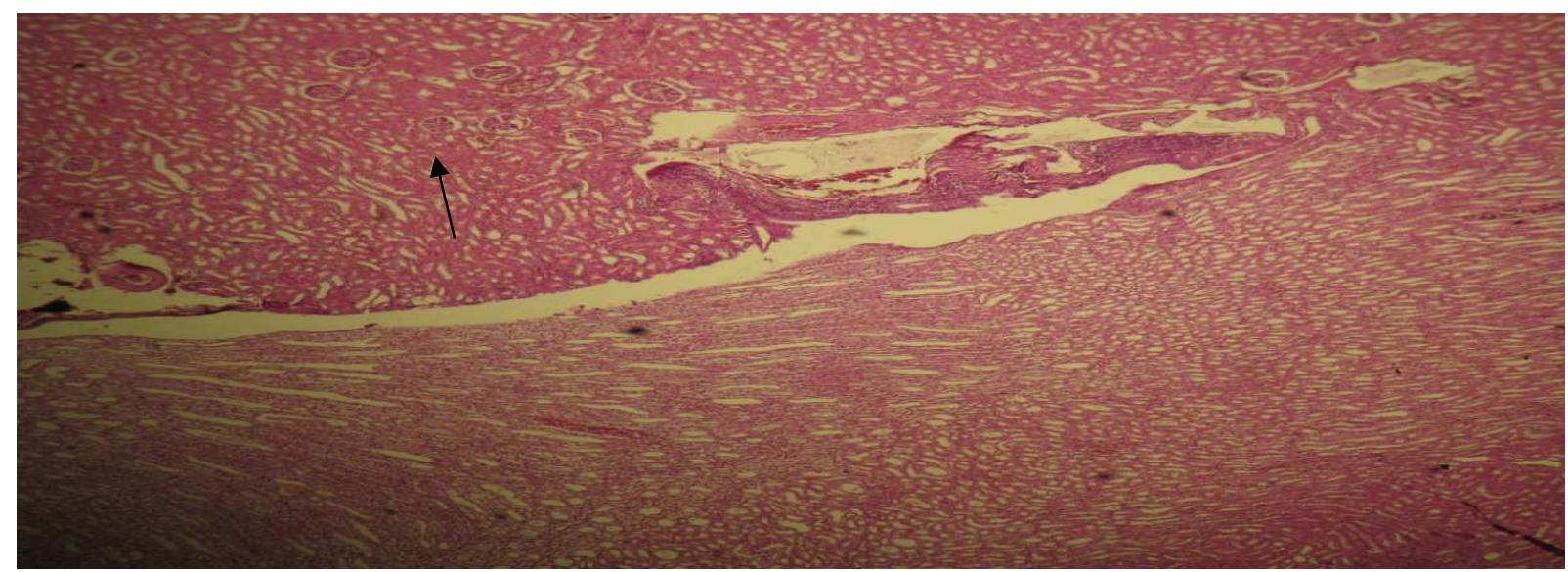

Plate 3: Section of the kidney shows no significant pathology, they showed normal kidney with the other cortex and inner medulla, the medulla is composed of renal pyramids which fits into a minor calyx. The cortex consists of numerous Bowman's capsule after ASBEEM $50 \mathrm{mg} / \mathbf{k g}$ administered for two weeks. H \& E Stain X 10 




Plate 4: Section of the kidney shows no significant pathology, they showed normal kidney with the other cortex and inner medulla, the medulla is composed of renal pyramids which fits into a minor calyx. The cortex consists of numerous Bowman's capsule after ASBEEM $100 \mathrm{mg} / \mathrm{kg}$ administered for two weeks. H \& E Stain X 10

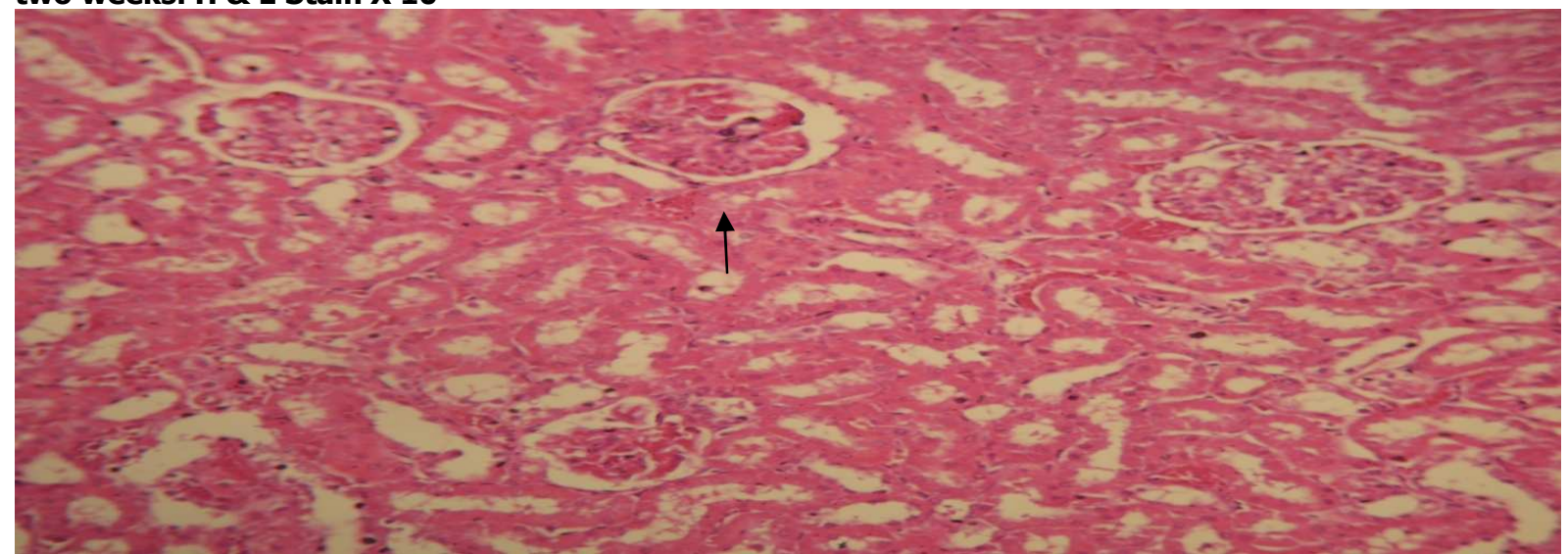

Plate 5: Section of the kidney shows no significant pathology, they showed normal kidney with the other cortex and inner medulla, the medulla is composed of renal pyramids which fits into a minor calyx. The cortex consists of numerous Bowman's capsule after ASBEEM $150 \mathrm{mg} / \mathrm{kg}$ administered for two weeks. H \& E Stain X 10

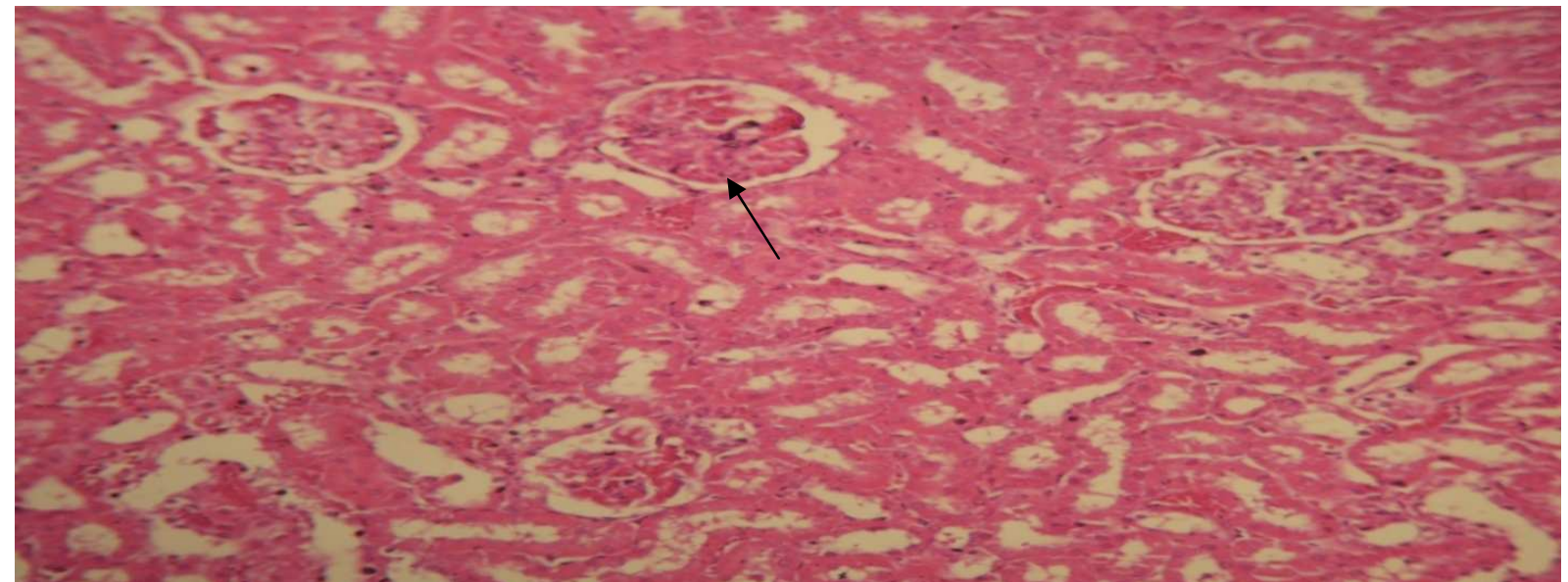

Plate 6: Section of the kidney shows no significant pathology, they showed normal kidney with the other cortex and inner medulla, the medulla is composed of renal pyramids which fits into a minor calyx. The cortex consists of numerous Bowman's capsule after ASBEEM $50 \mathrm{mg} / \mathrm{kg}$ administered for four weeks. H \& E Stain X 10 




Plate 7: Section of the kidney shows no significant pathology, they showed normal kidney with the other cortex and inner medulla, the medulla is composed of renal pyramids which fits into a minor calyx. The cortex consists of numerous Bowman's capsule after ASBEEM $100 \mathrm{mg} / \mathrm{kg}$ administered for four weeks. H \& E Stain X 10

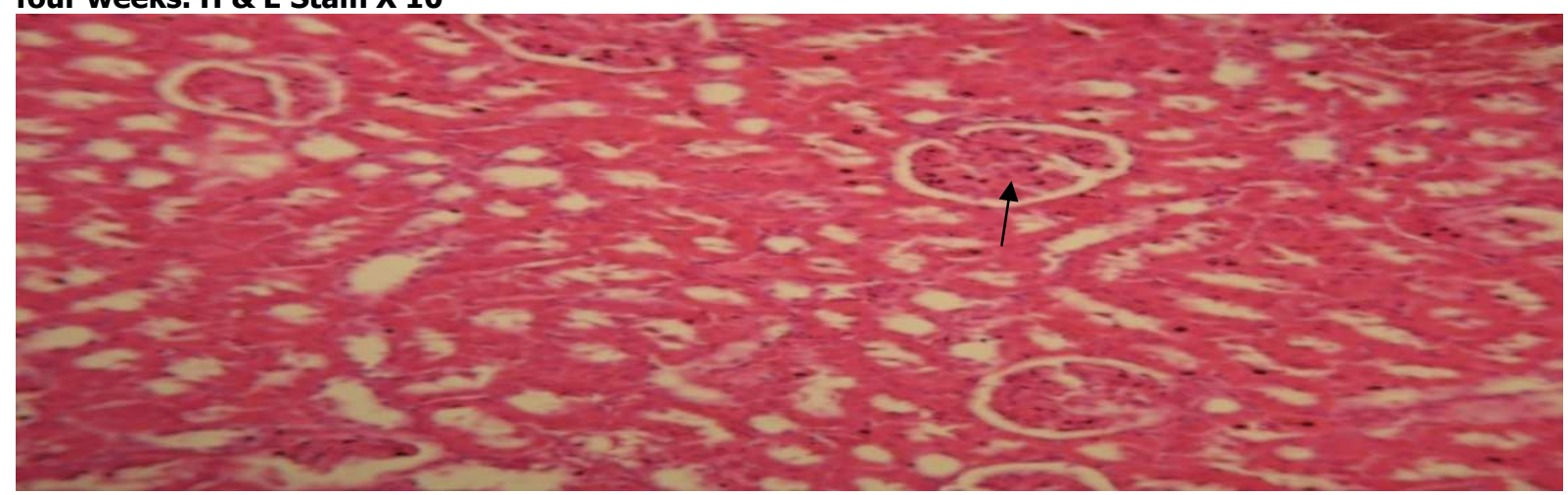

Plate 8: Section of the kidney shows no significant pathology, they showed normal kidney with the other cortex and inner medulla, the medulla is composed of renal pyramids which fits into a minor calyx. The cortex consists of numerous Bowman's capsule after ASBEEM $150 \mathrm{mg} / \mathrm{kg}$ administered for four weeks. H \& E Stain X 10

\section{DISCUSSION}

Nephrotoxicity and hepatotoxicity are the potential complications of acetaminophen, which is widely used in general medicine, and an assessment of its relative toxicity is important. A number of drugs or chemicals such as melatonin, vitamin $\mathrm{E}$ and $\mathrm{N}$-acetyl-cysteine have been used to prevent Acetaminophen-induced hepatic and renal injury (Sener et al., 2003). Serum surea ,creatinine, $\mathrm{Na}^{+}, \mathrm{K}^{+}, \mathrm{Cl}^{-}$levels were significantly increased $(\mathrm{P}<0.01)$ in groups treated with acetaminophen (Table 1 ) with the exception of $\mathrm{HCO}_{3}{ }^{-}$ which decreased demonstrating the deterioration of the renal function, in comparison with those of the normal control and acetaminophen and ASBEEM groups. These findings are consistent with the results of a previous study in which acetaminophen was administered to rats (Sener et al., 2003).

Primary toxicity of acetaminophen is the result of drug metabolism in both the liver and extrahepatic tissues (Gu et al., 2005). At therapeutic doses, acetaminophen is metabolized via glucuronidation and sulfation reactions occurring primarily in the liver which result in the water-soluble metabolites that are excreted via the kidney. The result of the metabolic conversion of acetaminophen by the microsomal P-450 enzyme system is that, a highly reactive intermediate, namely, Nacetyl-p-benzoquinone imine (NAPQI) is produced. This metabolite is then reduced by glutathione (GSH) (Bessems and Vermeulen, 2001). Acetaminopheninduced nephrotoxicity may be due to this metabolic activation of acetaminophen to the reactive metabolite, NAPQI (Hart et al., 1994). When large doses of acetaminophen are ingested, there is more severe GSH depletion as well as massive production of metabolites, which compounds the toxicity, leaving large amounts of reactive metabolite unbound. These intermediates then form covalent bindings with macromolecules on cellular protein (Bessems and Vermeulen, 2001). This process disrupts homeostasis and initiates apoptosis, or programmed cell death, leading to tissue necrosis and ultimately to organ dysfunction. 
Administration of ASBEEM for two and four weeks showed significant and dose dependent decreases $(P<0.01)$ in the levels of plasma urea, creatinine, $\mathrm{Na}^{+}$ $, \mathrm{K}^{+}, \mathrm{Cl}^{-}$in all the rats treated with acetaminophen while that of $\mathrm{HCO}_{3}^{-}$increased. This finding suggests a possible cure of kidney damage by the ASBEEM. They could be attributed to the presence of physiologically active alkaloids and flavoniods found in the plant extract (Na et al., 2006; Amer et al., 1991).

Acetaminophen -induced renal damage is consistent with acute tubular necrosis. In the present study, the results of histopathological examination showed a clear evidence of nephrotoxicity following the administration of acetaminophen in an overdose (Plate 2). Acute tubular necrosis was the most relevant histopathological change. These results are in agreement with those of the previous investigation describing the renal

\section{REFERENCES}

Abdel-Zaher, A.O., Abdel-Hady. R. H., Mahmoud, M.M. and Farrag, M. M. (2008).The Potential Protective Role of Alpha-Lipoid Acid against Acetominophen-Induced Hepatic and Renal Damage. Toxicol. 243:261-270.

Adeneye,A.A., Olagunju,J.A., Benebo,A.S, Eliass.O., Adisa,A.O., Idowu, B.O. and Oyedeji,M.O.(2008). Nephroprotective Effects of Aqueous Root Extract of Harungana Madagascariensis(L) In Acute and Repeated Dose Acetominophen Renal Injured Rats.Int.J,App/ Res. Nat. Prod.1:6-14.

Abraham, P. (2005). Vitamin C may be Beneficial in the Prevention of Paracetamol Induced Renal Damage. Clin. Exp. Nephrol. 9:24-30.

Amer, E.M., Shamma, M., and Freyer, A.J. (1991). The Tetracyclic Erythrina Alkaloids. J. Nat. Prod. 54:329-363.

Auwioro, O.G. (2010). Histochemistry and Tissue Pathology: Principles and Techniques. $2^{\text {nd }}$ Edition. University Press Delta State University, Abraka Nigeria.Pp. 561-568.

Bartels, H. and Bohmer, M. (1972). A Colorimetric Method for Determination of Serum Creatinine. J. Clin. Chem. Acta 37:193.

Bessems, J.G. and Vermeulen, N.P. (2001). Paracetamol (Acetaminophen)-Induced Toxicity: Molecular and Biochemical Mechanism, Analogues, and Protective Approaches. Rev. Toxicol. 31, 55138.

Burkill, H.M. (1995). The Useful Plants of West Tropical Africa. Vol. 3, Families J-L. Royal Botanic Gardens, Kew.Pp 30.

Cekmen, M., Iibey,Y.O., Ozbek, E., Simsek, A., Somay,A., and Ersoz, C. (2009). Cucumin Prevents Oxidative Renal Damage Induced by Acetominophen in Rats. Food Chem Toxicol.47:1480-1484.

Coulidiati, T.H., Millogo-Kone, H., Lamien-Meda, A., histological alterations following the administration of acetaminophen in an overdose (Abraham, 2005). The histopathological findings were in support of the biochemical changes recorded during the study, as the rats kidney in Plates 1, 3, 4 and 5 shows normal kidney pathology two and four weeks after administration of ASBEEM at varying doses. While those in Group II(acetaminophen treated) shows distortion of normal kidney architecture with dilation of renal tubules and collapsed of Bowmans capsule. These suggest that ASBEEM might posses nephrocurative effect against acetaminophen induced kidney damage in rats

\section{CONCLUSION}

The ASBEEM administered ameliorated the acetaminophen induced biochemical and histopathological renal changes. The effect of the aqueous extract was found to be dose dependant.

Yougbare-Ziebrou, M., Millogo-Rasolodimby J. and Nacoulma, O.G. (2011). Antioxidant and Bacterial Activities of Two Combretum Species from Burkina Faso. Res. J. Med. Plant.5:42-53.

Forrester, R. L., Wataji, L.J., Silverman, D.A. and Pierre, K.J. (1976). Enzymatic Method for Determination of $\mathrm{CO}_{2}$ in Serum. J. Clin. Chem. 22:243.

Ghosh, J., Das, J., Manna, P. and Sil, P.C. (2010).Acetominophen Induced Renal Injury Via Oxidative Stress and Tnf-7 Production:Therapeutic Potential of Arjunolic Acid. Toxicol.268,8-18.

Gu, J., Cui, H., Behr, M., Zhang, Q.Y., Yang, W.and Hinson, J.A. (2005). In vivo mechanisms of tissue-selective drug toxicity: effects of liverspecific knockout of the NADPH-Cytochrome P450 Reductase gene on Acetaminophen Toxicity in Kidney, Lung, and Nasal Mucosa. Mol. Pharmacol. 67, 623-630.

Guyton, A. C., and Hall, J.C. (2006). Text Book of Medical Physiology. $11^{\mathrm{h}}$ Edition, W. B. Saunders Company Philadelphia Pp 404-408.

Hart, S. G., Beierschmitt, W. P., Wyand, D. S., Khairallah, E. A., and Cohen, S. D. (1994).Acetaminophen Toxicity in CD-1 Mice. I. Evidence of a Role for In Situ Activation in Selective Covalent Binding and Toxicity. Toxicol. Appl. Pharmacol. 126: 267-275.

Hengy, B., Hayi-Slayman, D., Page, M., Christin,F., Baillon, J.J., Ber, C.E., Allaouchiche, B. and Rimmele, T.(2009).Acute Renal Failure After Acetaminophen Poisoning: Report of Three Cases. Can. J. Anaesth.56:770-774.

Henry, R. F. (1974). Clinical Chemistry Principle and Techniques, $2^{\text {nd }}$ Edition, Harper and Row, Hagerstown, M.D .Pp. 135-138.

Heywood, V. H. (1996). Les Plantes À Fleurs, 306 Familles De La Flore Mondiale. Nathan, Paris. 
Hodgson, E., (2010).A Text Book of Modern Toxicology. $4^{\text {th }}$ Edition. John Wiley and Sons, Inc., New Jersey.Pp.263-272,275-302.

Karthiswaran, S., Mirunalini, Dhamodharan, G., Krishnaveni, M., and Arulmozhi, V. (2010).Phytochemical Investigation of Methanolic Extract of the Leaves of Pergularia Daemia. J. Biol. Sci.10:242-246.

Kone, M. W. and Kamanzi Atindehou, K. (2009). West African Plants and Related Phytocompounds with Anti-Multidrug-Resistance Activity in: New Strategies Combating Bacterial Infection.WileyBlackwell, Weinheim,Germany. Pp. 136-164.

Kone, W. M., Atindehou, K. K., Terreaux, C., Hostettmann, K., Traore, D., and Dosso, M. (2004).Traditional Medicine in North CoteD'ivoire: Screening of 50 Medicinal Plants for Antibacterial Activity.J.Ethnopharmocol.93:4349.

Maruna, R. F. I. (1958).Clinical Chemistry.Acta. 2(1): 581.

Mitscher, A. L., Drake, S., Gollapudi, S. R., Simon, K., and Okwute, S. R. (1987). A Modern Look at Folkloric Use of Anti - Infective Agents. J. Nat. Prod. 50: 1025-1040.

Mitscher, A. L., Okwute, S. K., Gollapudi, S.R., Drake, S., and Avona, E., (1988). Antimicrobial Pterocarpans of Nigerian Erythrina Mildbraedii. Phytochem. 27: 3449-3452.

Na, M., Hoang, D. M., Njamen, D., Mbafor, J. T., Fomum, Z. T., Kim, B. Y., Oh, W. K., and Ahn, J. S. (2007). Inhibitory Effects of 2Arylbenzofurans from Erythrina Adenosine on Protein Tyrosinase Phosphatase-1b.Bioorg. Med.Chem. Lett.17:3868-3871.
Na, M., Jang, J., Njamen, D., Mbafor, J.T., Fomum, Z. T., Kim, B.Y., Oh, W. K., and Ahn, J. S. (2006).Protein Tyrosine Phosphate-1b Inhibitory Activity of Isophenylated Falconoid Isolated from Erythrina Mildbraedii. J. Nat. Prod. 69: 1572-1576.

Nguyen, P. H., Na, M., Dao, T. T., Ndinteh, D. T., and Mbafor J. T. (2010). New Stilbeniod With Inhibitory Activity On Viral Neuraminidases From Erythrina Addisonaea. .Bioorg. Med. Chem. Lett.20:6430-6344.

Njamen, D., Talla, E., Mbafor, J. T., Fomum, Z. T., Kamanyi, A., Mbanya, J. C., Cerda-Nicolas, M., Giner, R. M., Recio, M. C., and Rios, J. L. (2003). Anti-Inflammatory Activity of Erycristagallin A Pterocarpene Eur. J. Pharmacol. 468: 67-74.

Sener, G., Sehirli, A. O., and Ayanog Lu-Dulger, G. (2003). Protective Effects of Melatoin, Vitamin $\mathrm{E}$ and $\mathrm{N}$-Acetylcysteine Against Acetaminophen Toxicity in Mice. A Comparative Study. J. Pineal. Res. 35, 61-68.

Tchokouaha, R. F., Alexi, E., Chosson, T., Besson, and Skaltsounis, A.L. (2010).Erymildbraedin A and B,Two Novel Catatonic Dimethylprano-is Flavones from the Stem Bark of Erythrina Mildbraedii: Evaluation of their Activity Toward Endocrine Cancer Cells. J. Enzyme Inhibition Med. Chem.25:228-233.

Weatherburn, M. W. (1967). Phenol Hypochlorite Reaction for Determination of Ammonia.Anal. Chem.39:971-974.

White, W. L. (1970). Chemistry for Technologist. $3^{\text {rd }}$ Edition. The C.V. Mosby Co., St. Louis. Pp.182. 